\section{SINTESIS MEDIA TANAM DARI KULIT SINGKONG DENGAN PENAMBAHAN ARANG BAGASSE SEBAGAI POROGEN}

\author{
Nanik Astuti Rahman ${ }^{1}$ Iryanti Fatyasari Nata ${ }^{2}$ \\ Anis Artiyani ${ }^{3}$ Masrurotul Ajiza ${ }^{4}$ Lalu \\ Mustiadi ${ }^{5}$ Aladin Eko Purkuncoro ${ }^{5}$ \\ 1 Program Studi Teknik Kimia, Institut Teknologi Nasional \\ Malang \\ 2 Program Studi Teknik Kimia, Universitas Lambung \\ Mangkurat \\ 3 Program Studi Teknik Lingkungan, Institut Teknologi \\ Nasional Malang \\ 4 Program Studi Teknik Geodesi, Institut Teknologi \\ Nasional Malang \\ ${ }^{5}$ Program Studi Teknik Mesin, Institut Teknologi Nasional \\ Malang \\ $\bowtie \quad$ nanik.astuti@lecturer.itn.ac.id
}

\section{Pendahuluan}

Industri pengolahan singkong memberikan kontribusi limbah berupa kulit singkong yang cukup banyak. Selama ini kulit singkong hanya digunakan sebagai campuran makan ternak, selebihnya dibiarkan pada lahan terbuka, ketika kulit singkong terfermentasi akan menimbulkan bau yang tak sedap. Pemandangan itu kerap terlihat di daerah Desa Ngenep Karangploso Kabupaten Malang karena daerah ini merupakan kawasan industri keripik singkong.

Tanah yang subur, membawa daerah ini menjadi salah satu daerah pemasok sayuran di daerah Malang, seperti sayuran dan palawijaya. Hampir di setiap rumah ditemui halaman yang penuh dengan tanaman sayuran. Hasil panen sayuran dan palawijaya selain dikonsumsi sendiri juga dijual karena memang jumlahnya berlimpah.

Keadaan alam yang tidak menentu menyebabkan penggunaan pupuk menjadi lebih besar, hal ini karena curah hujan yang tinggi akan melarutkan dan menghanyutkan pupuk yang diberikan ke tanaman. Berdasarkan situasi yang terjadi dimana masalah lingkungan belum teratasi karena timbunan limbah kulit singkong, dan munculnya masalah pada sektor pertanian, maka dilakukan pengolahan limbah kulit singkong menjadi media tanam bernutrisi.

Kulit singkong berpotensi sebagai media tanam karena mengandung senyawa karbon, hydrogen, oksigen, nitrogen, sulfur,dan air, masing-masing adalah $59,31 \%$, 9,78\%, 28,74\%, 2,06\%, 0,11\% dan $11,4 \%$.
Penggunaan serbuk kulit singkong, selain menyediakan unsur hara yang dibutuhkan tanaman, pengalihan bentuk kulit singkong menjadi serbuk dimaksudkan untuk memperbesar porinya sehingga air akan terperangkap didalamnya. Pembuatan media tanam ini dilakukan dengan cara membersihkan kulit singkong dari kotoran menempel, mengeringkan dan mengecilkan ukurannya dengan blender. Serbuk kulit singkong dicampurkan dengan arang bagasse dan tanah dengan ratio $(\% \mathrm{w} / \mathrm{w}) \quad 50 \%, 45 \%$ dan $5 \%$. Campuran yang sudah dicampur homogen didiamkan selama 10 menit, setelah itu media tanam siap diaplikasikan. Kegiatan ini dilakukan di Desa Ngenep, Karangploso Kabupaten Malang. Untuk mendapatkan media tanam yang baik, campuran antara serbuk kulit singkong, sekam padi dan tanah berturut-turut adalah $55 \% ; 45 \% ; 5$. Kandungan unsur hara yang terdapat dalam media tanam dari kulit singkong ini adalah $2,9 \%$ $\mathrm{N}, 3,0 \% \mathrm{P}$ dan $3,5 \% \mathrm{~K}$.

Kata kunci: kulit singkong, media tanam, arang bagasse, porogen

Diajukan: 22 April 2021

Direvisi: 24 Juni 2021

Diterima: 28 Juni 2021

Dipublikasikan online: 29 Juni 2021

Unsur-unsur tersebut dibutuhkan untuk pertumbuhan tanaman (Akanbi, 2007).

Sumber kalium yang dibutuhkan tanaman, biasanya disediakan dalam bentuk pupuk kalium $(\mathrm{KCl})$, harganya makin mahal, sehingga diperlukan eksplorasi sumber kalium, seperti misalnya dari biomass, yaitu kulit singkong. Eksplorasi sumber kalium lainnya adalah abu hasil pembakaran sisa tanaman unit pengolahan gula kelapa (Baon dan Sugiyanto, 2011).

Seperti diketahui bahwa pemanfaatan kulit singkong selama ini selain sebagai campuran pakan ternak, digunakan juga sebagai bahan baku pembuat gula dan pupuk cair organik. Pemanfaatan lainnya, yang dilakukan oleh Sigit Pratama tahun 2017, dimana kulit singkong digunakan sebagai media tumbuh jamur tiram putih, hal ini karena didalam kulit singkong terdapat kandungan unsur $\mathrm{N}$ dan $\mathrm{C}$ masing-masing sebanyak 2,06\% dan 59,31\% (Hikmah, 2015). Kandungan nutrisi dalam kulit singkong ini setara dengan kadar $\mathrm{N}$ dan $\mathrm{C}$ yang ada dalam kulit kopi, yaitu masing-masing sebesar 2,98\% dan 45,3\% (Baon dkk., 2005). Besarnya kandungan karbon organik dalam kulit singkong dapat meningkatkan kualitas fisik media tanam melalui aktivitas biologi dan pembentukan struktur yang baik (Sutanto, 2002). Bahan organik memberikan pengaruh sebagai agen pengikat dalam proses pembentukan agregat media tanam (Sharma dan Bhusman, 2001), dimana tingkat agregasi dan permeabilitas media tanam meningkat, porositas media juga bertambah dan tingkat kepadatan berkurang (Zang, dkk. 1997). Hal ini berpengaruh positif terhadap peningkatan perkembangan akar (Hati et al., 2006).

Cara mensitasi artikel ini:

Rahman NA, Nata IF, Artiyani A, Ajiza M, Mustiadi L, Purkuncoro AE (2020) Sintesis Media Tanam dari Kulit Singkong dengan Penambahan Arang Bagasse sebagai Porogen. Buletin Profesi Insinyur 4(1) 042-047 
Dalam sintesis media tanam pada penelitian ini, ditambahkan abu bagasse sebagai porogen. Penambahan abu bagasse meningkatkan jumlah karbon organik pada media tanam. Keberadaan abu organik dapat memperbaiki sifat kimia dan biologi media tanam karena menyediakan energi yang diperlukan bagi aktivitas biologi tanah sehingga meningkatkan penambatan nitrogen dari udara (Kahindi dkk, 1997).

Arang bagasse, sudah banyak disintesis dan diaplikasikan untuk tujuan tertentu, seperti silica gel (Affandi dkk, 2009), silica-amine sebagai adsorben gas CO2 (Rahman dkk, 2015; Rahman dkk, 2018) dengan memanfaatkan sifat porositasnya (Manocha, 2003).

Penggunaan arang bagasse sebagai adsorben untuk mereduksi limbah phenol (Endahwati, 2009), limbah protein (Purnawan dkk, 2012), pada air tercemar (Khadijah dkk, 2012), reduksi logam berat (Herlandien, 2013 ; Asbhani, 2013 ; Apriliani, 2010) maupun sebagai filter pada pengolahan air bersih, menjadikan arang bagasse banyak digunakan sebagai material penelitian (Khairurrijal, 2009).

Berdasarkan uraian dan analisis situasi maka tujuan dari penelitian ini adalah memanfaatkan kulit singkong sebagai media tanam. Respon tanaman terhadap media tanam yang disintesis dari kulit singkong dan pengaruhnya terhadap perkembangan tumbuhan tanaman seperti pertumbuhan akar, jumlah daun dan tinggi tanaman dipelajari secara detail.

\section{Metode}

Kegiatan ini dilakukan di Desa Ngenep, Karangploso Kabupaten Malang, pada bulan Oktober - November 2020, dengan kondisi curah hujan sedang.Pembuatan media tanam dari kulit singkong, dilakukan dengan menambahkan bahan pembantu lainnya berupa abu bagasse dan tanah yang berfungsi sebagai perekat.

Pembuatan media tanam dari kulit singkong ini mengadopsi dari invensi yang diajukan oleh Rahman, dkk (Paten No. S00202007996), dimana prosedurnya dilakukan dengan cara sebagai berikut: Pembuatan media tanam ini dimulai dengan membersihkan kulit singkong dengan mencuci di air mengalir. Ini dimaksudkan untuk menghindari sumbatan pori pada kulit singkong. Setelah dicuci, kulit singkong dikeringkan dengan konvensional melalui sinar matahari atau dengan oven pada temperatur $50{ }^{\circ} \mathrm{C}$ selama $3 \mathrm{jam}$. Pengecilan ukuran dengan cara memblender kering kulit singkong dilakukan untuk medapatkan luas permukaan material yang lebih besar, sehingga proses adsorpsi terhadap air dan unsur hara dapat terjadi dengan baik. Serbuk kulit singkong dicampurkan dengan arang bagasse dan tanah dengan perbandingan berat (\%w/w) 50\%; 45\%; 5\%. Setelah itu, dicampur hingga homogen, dan selanjutnya didiamkan selama 10 menit untuk memberikan kesempatan keluarnya udara dan gas yang ada didalamnya.

Aplikasi untuk media tanam ini adalah sebagai berikut: media diletakkan pada pot, selanjutnya tanaman dimasukkan ke dalam pot dan terakhir pot diisi penuh dengan media. Perlu diperhatikan bahwa tidak boleh menekan-nekan media tanam karena hal ini menyebabkan tersumbatnya pori pada material media tanam sehingga tujuan dari penyerapan air dan menyimpannya tidak terpenuhi.

Keberadaan air dibutuhkan tanaman untuk berfotosintesis, mengaktifkan reaksi enzimatik, menjaga kelembaban dan membantu perkecambahan biji (Asngat, 2013).

\section{Hasil Kerja}

Pertumbuhan tanaman, dapat dilihat dari bertambah tingginya tanaman tersebut. Pertambahan tinggi tanaman diindikasikan bahwa kebutuhan unsur hara untuk tumbuh terpenuhi dengan cukup. Pertumbuhan tanaman dipengaruhi oleh faktor-faktor seperti sinar matahari, suhu dan kelembaban, unsur hara, dan media tanam. Sinar matahari, suhu dan kelembaban memberikan efek terhadap proses fotosintesis tanaman. Unsur hara yang butuhkan tanaman harus tercukupi untuk proses tumbuh dan berkembangnya tanaman.

Media tanam yang baik akan memberikan efek tumbuh dalam hal ruang gerak tanaman. Hal ini bisa dijelaskan bahwa kondisi media tanaman yang baik haruslah berongga dan mempunyai ruang, dimana kondisi ini dibutuhkan akar untuk tumbuh dengan baik. Tetapi adanya pori atau ruang yang didalam media tanam ditunjukkan dengan kondisi gembur tidak boleh terlalu besar. Hal ini bisa menyebabkan akar dengan mudah akan tercerabut dari media (Perwitasari, B., 2012)

Pada media tanaman yang disintesis dari kulit singkong ini, dalam proses pembuatannya ditambahkan abu bagasse dan tanah bagian atas (top soil). Kulit singkong, seperti diketahui merupakan material berpori, dimana uji porositas terhadap kulit singkong dikonfirmasi dengan analisis Citra Scanning Electron Microscope (SEM).

\section{Karakterisasi material}

Serbuk kulit singkong bisa dijadikan sebagai bahan media tanam karena merupakan material berpori, hal ini bisa dilihat dari hasil analisis SEM terhadap serbuk kulit singkong (Gambar 1). Dari Gambar 1 dapat dilihat bahwa serbuk kulit singkong merupakan material berpori, ditandai dengan adanya pori-pori pada visualisasi dengan SEM.

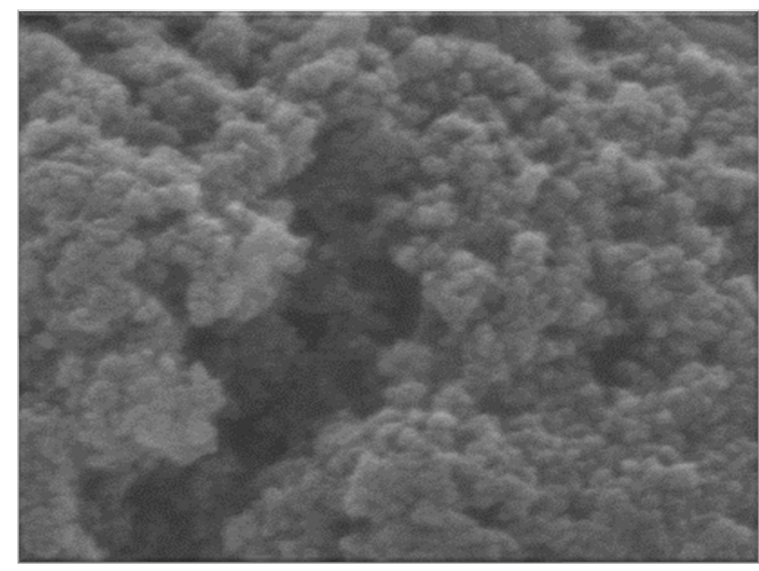

Gambar 1. Citra SEM Serbuk kulit singkong perbesaran $50.000 x$ 
Konfirmasi data adanya porositas pada kulit singkong juga terlihat dari hasil analisis pori menggunakan Brunaur, Emmett and Teller (BET), seperti yang ditampilkan pada Tabel 1 . Pori pada material akan digunakan sebagai penyimpan air sehingga media tanam dapat menyediakan air dalam waktu lebih lama.

Tabel 1. Hasil analisis porositas dengan BET

\begin{tabular}{|c|c|c|}
\hline No & Parameter & Besaran \\
\hline 1 & Luas permukaan $\left(\mathrm{m}^{2} / \mathrm{g}\right)$ & 19,519 \\
\hline 2 & Diameter pori $(\mathrm{nm})$ & 3,413 \\
\hline 3 & Volume pori $(\mathrm{cc} / \mathrm{g})$ & 0,030 \\
\hline
\end{tabular}

Syarat media tanam yang baik harus memenuhi syarat sebagai berikut: a) ada rongga untuk akar tanam, artinya media tanam harus gembur tetapi tidak boleh terlalu gembur karena akan menyebabkan akar tanaman mudah tercabut. Media tanam juga tidak boleh terlalu padat karena akan sulit tumbuh ; b) media penyusun yang berpori akan memudahkan air masuk dan tersimpan lebih lama sehingga kondisi tetap lembab dan kebutuhan air tercukupi ; c) media tanam harus dapat menyediakan kebutuhan unsur hara yang diperlukan tanaman (Suryana, 2000). Dalam kulit singkong terkandung unsur-unsur yang dibutuhkan tanaman.

\section{Analisis Unsur Hara}

Unsur NPK yang dibutuhkan tanaman secara teoritis adalah $\mathrm{N}: 1,37-3,21 \%, \mathrm{P}: 2,22-3,81 \%$, dan $\mathrm{K}: 2,48-4,24 \%$. Unsur hara yang terkandung dalam media tanam di analisis menggunakan Gas Chromatography Mass Spectroscopy (GCMS). Analisis ini untuk mengetahui jenis dan kandungan senyawa dalam suatu sampel baik secara kualitatif dan kuantitatif. Hasil analisis GCMS media tanam kulit singkong ditunjukkan pada Tabel 2

\section{Hasil Pengamatan}

Unsur karbohidrat yang terdapat dalam kulit singkong sangat membantu pemenuhan akan karbohidrat tanaman yang digunakan dalam proses pembelahan sel, hal ini bisa terjadi karena dinding sel tumbuhan terbuat dari selulosa dan protoplasmanya terbuat dari karbohidrat.

Tabel 2. Hasil analisis GCMS media tanam

\begin{tabular}{|c|c|c|}
\hline No & Unsur Hara & Kandungan (\%) \\
\hline 1 & N (nitrogen) & 2,9 \\
\hline 2 & P (phosphor) & 3,0 \\
\hline 3 & K (kalium) & 3,5 \\
\hline
\end{tabular}

Sekam padi yang dijadikan sebagai campuran dalam pembuatan media tanam ini, dilakukan dengan membakar sekam hingga berbentuk arang pada suhu $230^{\circ} \mathrm{C}$ selama 2 jam. Arang sekam ini dapat memberikan fungsi penetraslisasi racun, meningkatkan daya adsorpsi terhadap air sehingga merangsang pertumbuhan mikroorganisme yang bermanfaat bagi tanaman. Sifatnya yang berongga juga menjadikan arang sekam dapat memperbaiki aerasi dan drainase pada media tanam (Nurshanti, 2009)

Material lain yang mempunyai karakteristik yang sama dengan arang sekam adalah arang ampas tebu atau biasa disebut dengan bagasse. Arang bagasse ini mempunyai pori yang bermanfaat memerangkap unsur hara pada media tanam sehingga mampu bertahan untuk memenuhi kebutuhan gizi dan mineral tanaman. Selain itu, sifat porous dari arang bagasse ini juga dapat memberikan ruang pada media tanam sehingga akar-akar tanaman dapat bergerak bebas dan dapat bernafas sehingga pertumbuhan tanaman tidak terhambat.

Porositas pada ampas bagasse juga dapat berfungsi mencegah erosi pupuk yang ditambahkan pada media tanam untuk menambahkan kebutuhan nutrisi tanaman.

Selain arang sekam, tanah bagian atas yang sering disebut dengan top soil, merupakan gabungan dari tanah pasir dan lempung, ditambahkan untuk membantu ketahanan posisi tanaman dan juga membantu proses peresapan terhadap air dan unsur hara.

Unsur-unsur pembentuk media tanam, semuanya disiapkan untuk menjadi media tanam yang baik. Keberhasilan media tanam dari kulit singkong ditunjukkan dengan tumbuhnya tanaman (kangkung, cabe dan pakcoy) dengan baik, yaitu adanya respon tumbuh terhadap tinggi tanaman, jumlah daun dan panjang akar.

Tinggi tanaman yang ditumbuhkan dengan media tanam singkong ditunjukkan pada Gambar 2. Pada Gambar 2, terlihat bahwa ketiga tanaman tumbuh dengan baik yang ditunjukkan dengan respon tinggi tanaman yang bertambah seiring dengan masa tanam. Hal ini juga menginformasikan bahwa media tanam dari kulit singkong ini sangat cocok untuk tanaman kangkung, cabe dan pakcoy.

Pengamatan terhadap respon jumlah daun tanaman kangkung, cabe dan pakcoy dilakukan pada minggu kedua setelah masa tanam. Perlakuan awal berupa persemaian biji dilakukan pada media tanam dan dibiarkan hingga biji tumbuh dengan baik dan daun tanaman mulai terbentuk. Setelah daun tanaman mulai tumbuh, baru kemudian diamati respon pertumbuhannya di awal minggu kedua.

Pertumbuhan daun di ketiga tanaman ditunjukkan pada Gambar 3. Terlihat bahwa ketiga tanaman memberikan respon yang cenderung sama, yaitu jumlah daun meningkat seiring dengan bertambahnya masa tanam. Penjelasan dari kondisi ini adalah sebagai berikut, daun merupakan bagian tanaman yang akan tumbuh dengan baik jika kebutuhan akan unsur hara berupa nitrogen (N), dan karbohidrat terpenuhi. Kebutuhan akan karbohidrat ini digunakan oleh tanaman untuk aktivitas perpanjangan dan pembelahan sel. Karbohidrat pada media tanam ini dipenuhi oleh kulit singkong, sehingga jumlah daun ketiga tanaman bisa tumbuh dan berkembang dengan baik. (Harjadi, 1984).

Gambar 4, menunjukkan respon panjang akar tanaman kangkung, cabe dan pakcoy menggunakan media tanam dari kulit singkong dengan selang masa tanam 2-8 minggu. Pada Gambar 4, terlihat adanya pertumbuhan panjang akar yang sangat cepat. Kecenderunga pertambahan panjang akar pada ketiga tanaman ini adalah sama yaitu meningkat secara signifikan. Hal ini bisa dijelaskan bahwa kebutuhan terhadap unsur hara berupa nitrogen $(\mathrm{N})$ yang sangat dibutuhkan oleh tanaman untuk membentuk bagian-bagian vegetatif dan generatif, seperti daun dan akar, sudah terpenuhi. Fenomena ini juga dijelaskan oleh Haryanto (2002) dalam penelitiannya yang menyebutkan bahwa pertumbuhan dan perkembangan akar tanaman sangat dipengaruhi oleh kondisi tanah baik secara kimia, biologi maupun fisik dan ketersedian bahan organik yang berupa pupuk atau vitamin tanaman. 


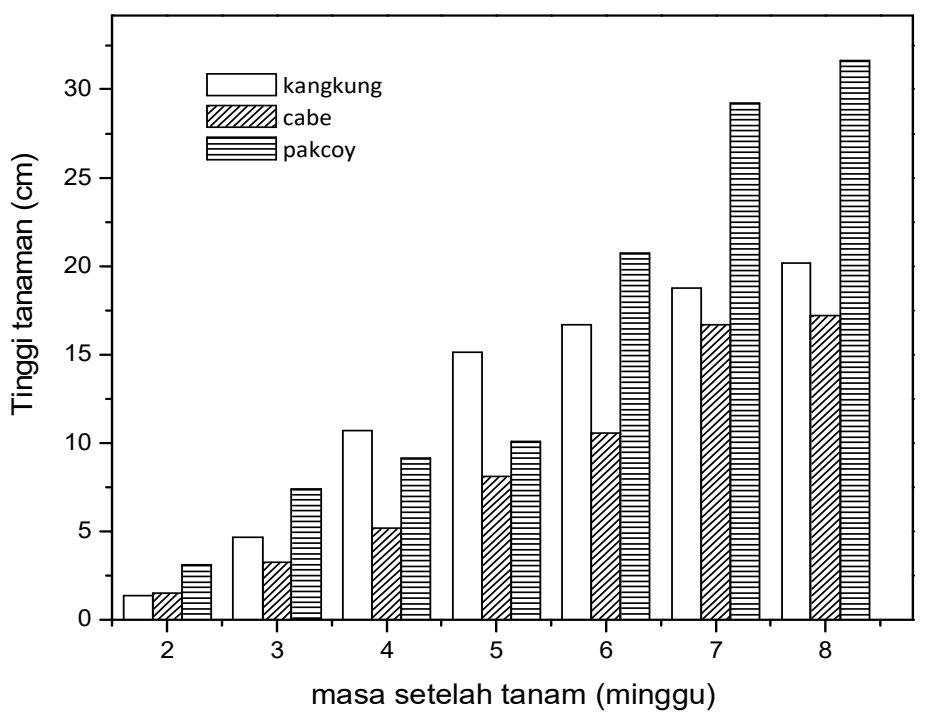

Gambar 2. Respon tinggi tanaman pada selang masa masa tanam

\section{Kesimpulan}

Proses pembuatan media tanam dari kulit singkong telah berhasil dilakukan. Pemanfaatan limbah kulit singkong yang menjadi permasalahan di lingkungan Desa Ngenep Kabupaten Malang berhasil diselesaikan. Aplikasi media tanam yang dilakukan pada tanaman sayuran yaitu kangkung, cabe dan pakcoy, menunjukkan pertumbuhan yang bagus. Respon perlakuan terhadap tinggi tanaman, jumlah daun dan panjang akar menunjukkan respon positif. Kandungan unsur hara NPK pada media tanam ini secara berturut-turut adalah 2,9\%; 3,0\% dan 3,5\%.

Hasil yang sudah dicapai dari pengolahan kulit singkong ini selain media tanam bernutrisi, kebutuhan akan pupuk dapat di penuhi secara swadaya oleh masyarakat. Masalah lingkungan juga teratasi karena timbunan kulit singkong sudah tidak ada lagi.

\section{Ucapan Terimakasih}

Ucapan terima kasih kami sampaikan kepada Pimpinan ITN Malang yang telah membiayai kegiatan penelitian dan pengabdian kepada masyarakat melalui skema hibah internal ITN Malang dengan No. SK Rektor ITN Malang No. ITN.05.070/I.REK/2020 tanggal 11 Mei 2020. Terima kasih juga kami sampaikan kepada masyarakat Desa Ngenep Karangploso Kabupaten Malang atas kerjasama yang baik sehingga kegiatan berjalan lancar dan bermanfaat.

\section{Referensi}

Abdullah. Mikrajuddin. Khairurrijal. 2009, “Karakterisasi Nanomaterial, Jurnal Nanosains dan Nanoteknologi", ISSN 1979-0880, 56-781(2).

Akanbi, et al. (2007). "The Use of Compost Extract as Foliar Spray Nutrient Source and Botanical Insecticide in Telfairia occidentalis". World Journal of Agricultural Sciences. 3, (5), 642-652.
Apriliani, A. 2010, Pemanfaatan arang ampas tebu sebagai absorben ion logam $\mathrm{Cu}, \mathrm{Cd}, \mathrm{Cr}$, dan $\mathrm{Pb}$ dalam air llimbah. Jurnal lingkungan.

Asbhani, 2013. Pemanfaatan Limbah Ampas Tebu Sebagai Karbon Aktif untuk Menurunkan Kadar Besi Pada Air Sumur, Jurnal Teknik Sipil Untan 13(1), 7586.

Asngat, Aminah, Nunik Kristianingsih. 2013. Modul Praktikum Fisiologi Tumbuhan. Surakarta: Universitas muhammadiyah SPeneurakarta.

Baon, J.B.; R. Sukasih \& Nurkholis (2005). Laju dekomposisi dan kualitas kompos limbah padat kopi: pengaruh aktivator dan bahan baku kompos. Pelita Perkebunan, 21, $31-42$

Baon, J.B dan Suhiyanto (2011). Sifat Kimia Tanah Akibat Abu Asal Tanaman Pengganti Pupuk Kalium dan Nilai Konversinya, Pelita Perkebunan 27(2) 2011, 98-108

Endahwati, L., (2009). Penurunan Limbah Phenol Dengan Menggunakan Arang Aktif Bagasse Dan Tempurung Kelapa. Prosiding Seminar Nasional Teknik Kimia Soebardjo Brotohardjono VI, D9,1-3.

Harjadi, 1984. Pengaruh Bahan Stimulator EM4 Terhadap Pertumbuhan dan Produksi Kangkung Darat.Agromedia Pustaka, Jakarta.

Haryanto, T. Suhartini dan E. Rahayu.2002. Tanaman Sawi dan Selada.Jakarta : Penebar Swadaya.

Hati, K.M., Mandal, K.G., Misra, A.K., Ghosh, P.K. dan Bandyopadhyay, K.K. 2006. Effect of inorganic fertilizer and farmyard manure on soil physical properties, root distribution, and wateruse efficiency of soybean in Vertisols of Central India. Bioresource Technology 97, 2. 182-2.188.

Herlandien, YL. 2013. Pemanfaatan Arang Aktif Sebagai Absorban Logam Berat Dalam Air Lindi di TPA Pakusari Jember. Skripsi, Fakultas Matematika dan IImu Pengetahuan Alam Universitas Jember.

Kahindi, J.H.P.; P. Woomer; T. George; F.M.S. Moreira; N.K. Karanja \& K.E. Giller (1997). Agricultural intensification, soil biodiversity and agroecosystem 


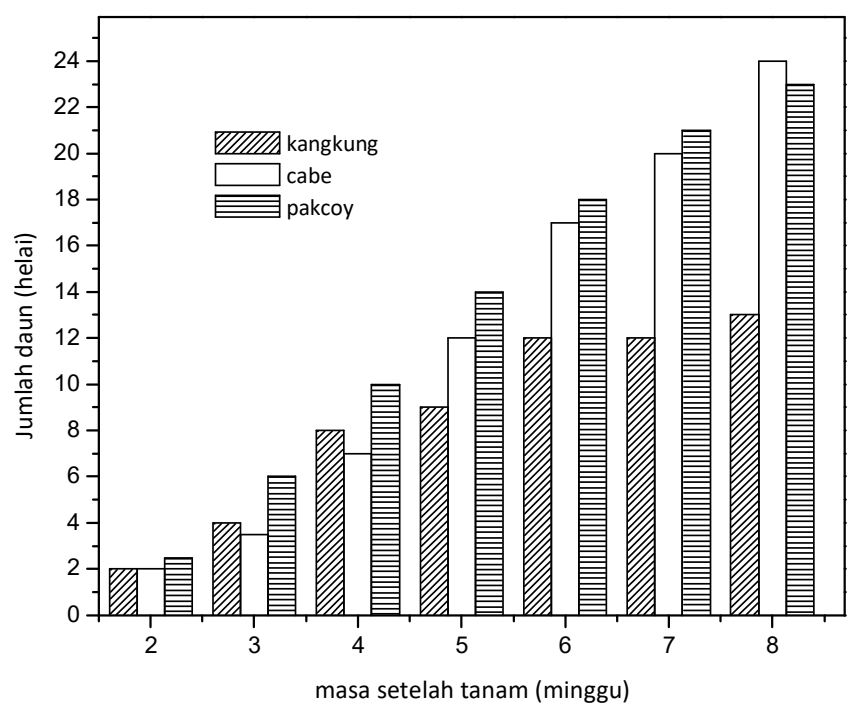

Gambar 3. Respon jumlah daun tanaman pada selang masa masa tanam

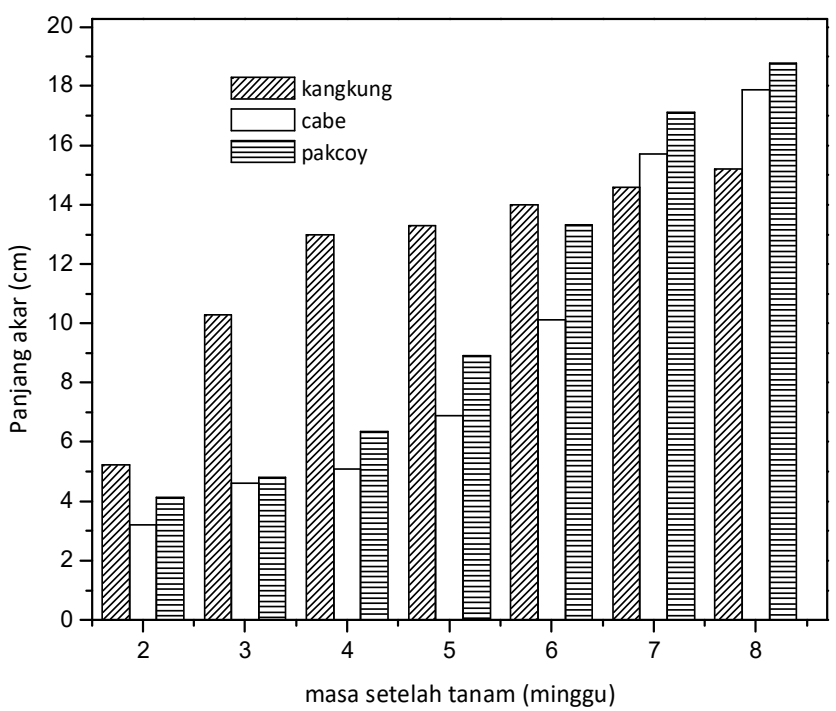

Gambar 4. Respon panjang akar tanaman pada selang masa masa tanam

function in the tropics: the role of nitrogen-fixing bacteria. Applied Soil Ecology, 6, 55-76.

Khadijah S, Siti Fatimah C.O, N Aina Misnon, F, Hanim, K. 2012, "Utilization of Sugarcane Bagasse In The Production Of Activated Carbon For Groundwater Treatment", International Journal of Engineering and Applied Sciences 2 (1).

Manocha, S.M. 2003. Porous Carbons. Sadhana 28 : 335348.

Nurshanti, D.F. 2009. Pengaruh pemberian pupuk organik terhadap pertumbuhan dan hasil tanaman sawi caisim (Brassica juncea L.). Jurnal Agronobis, 1(1):89-98.

Perwitasari, B., Mustika T., Catur W. 2012. Pengaruh Media Tanam dan Nutrisi Terhadap Pertumbuhan dan Hasil Tanaman Pakcoy (Brassicachinensis) Dengan Sistem Hidroponik. Agrovigor : 5 (1) : 14-25.

Purnawan, C., Martini , I., Afidah, S. (2014). Penurunan Kadar Protein Limbah Cair Tahu dengan Pemanfaatan Karbon Bagasse Teraktivasi. Jurnal Manusia dan Lingkungan, 21(2): 143-148.
Rahman, N.A., Widhiana, I., Juliastuti S.R., Setyawan, H. (2015), Synthesis of mesoporous silica with controlled pore structure frombagasse ash as a silica source. Colloids and Surfaces A: Physicochemical and Engineering Aspect; ISSN: 0927-7757; Colloids and Surfaces A: Physicochem. Eng. Aspects 476 (2015) 17

Rahman, N.A., Widiyastuti, Sigit, D., Ajiza, M., Sujana, W. (2018). The Effect of Various Acids to the Gelation Process to the Silica Gel Characteristic Using Organic Silica. IOP Conf. Series: Materials Science and Engineering 299 (2018) 012049

Rahman, N.A., Adiputra G. A., Ajiza, M. (2020), "Media Tanam Berbahan Dasar Kulit Singkong, Paten No. S00202007996.

Sharma, P.K. and L. Bhushan, L. 2001. Physical characterization of a soil amended with organic residues in a rice-wheat cropping system using a single value soil physical index. Soil and Tillage Research 60, 143-152. 
Suryana. 2000. Kulit singkong sebagai pupuk alternatif tanaman rumput unggul. Bogor: balai penelitian ternak, P.O. Box 221, Bogor 16001.
Sutanto, R. 2002. Penerapan Pertanian Organik. Kanisius. Yogyakarta

Zhang, H.; K.H. Hartge \& H. Ringe (1997). Effectiveness of organic matter incorporation in reducing soil compactibility. Soil. Sci. Soc. Am. J., 61, 239-245. 